\title{
Could the Procedures and Instructions for Promoting Cooperative Learning Affect Teachers' Practices in EFL Classrooms?
}

\author{
Nurah Saleh Alfares \\ Department of Curriculum and Instruction, College of Education, Umm AL-Qura University, Saudi Arabia \\ *Corresponding Author: nsfares@uqu.edu.sa
}

Received July 17, 2020; Revised September 12, 2020; Accepted September 29, 2020

\section{Cite This Paper in the following Citation Styles}

(a): [1] Nurah Saleh Alfares, "Could the Procedures and Instructions for Promoting Cooperative Learning Affect Teachers' Practices in EFL Classrooms?," Universal Journal of Educational Research, Vol. 8, No. 11B, pp. 5833 - 5848 , 2020. DOI: 10.13189/ujer.2020.082217.

(b): Nurah Saleh Alfares (2020). Could the Procedures and Instructions for Promoting Cooperative Learning Affect Teachers' Practices in EFL Classrooms?. Universal Journal of Educational Research, 8(11B), 5833 - 5848. DOI: 10.13189/ujer.2020.082217.

Copyright $\mathrm{C} 2020$ by authors, all rights reserved. Authors agree that this article remains permanently open access under the terms of the Creative Commons Attribution License 4.0 International License

\begin{abstract}
This study aims to explore how teachers' application of the procedures and instructions for promoting cooperative learning (CL) affects their practices. The purpose of this study is to explore teachers' behaviors and perceptions while applying procedures and instructions to encourage $\mathrm{CL}$ in their teaching practice. The problem is that the application of CL in Saudi English as a foreign language (EFL) educational environments tend to be used more in group arrangements than as an effective technique to encourage learners' communication and interaction. Still, the EFL literature has recommended appropriate procedures to promote $\mathrm{CL}$ for teachers. In this study, nine participating teachers were provided these $C L$ procedures to apply in their daily teaching practice. The researcher applied mixed methods as follows: quantitative data from structured observations during EFL lessons and qualitative data from the teachers' daily reports and open-ended questionnaire answers. The findings told that most of the teachers felt that the procedures helped them support their students and encourage them to work effectively and cooperatively in groups. Moreover, the findings indicated that the instructions helped the EFL teachers increase their students' interaction and communication by prompting them to apply CL procedures. However, the majority of the teachers did not appropriately encourage their EFL learners to engage in CL even though they were aware of the procedures.
\end{abstract}

Keywords Cooperative Learning, EFL, Procedures, Instructions, Teachers' Practices

\section{Cooperative Learning in EFL Lessons: What to Do and What to Avoid}

Cooperative learning (CL) is essential to learning a foreign language, as it opens opportunities for learners to communicate and interact with others. However, CL's application is not sufficient enough to help learners get its complete benefits (Millis, 2014; Gillies, 2004; Azizinezhad et al., 2013). There should be guidelines and procedures for how learners interact to complete the tasks provided by EFL teachers (Millis, 2014; Koppenhaver \& Shrader, 2003; Birmingham \& McCord, 2004). Moreover, the type of group task should have some criteria that reflect on learners through interaction.

Teachers' CL procedures for group work may include the following: how to assign students into groups, how to arrange the classroom environment, the roles given to group members, the social skills that are to be developed, the size of the group, the academic tasks to be set, and how to evaluate and give feedback (Gillies, 2003; McCafferty et al., 2006; Cohen, 2014). Further, teachers need to consider 
suitable procedures to prepare a suitable environment. Table 1 summarizes the suggested procedures in the literature to help increase interactions in CL (Brown, 2001; Azizinezhad et al., 2013; Koppenhaver \& Shrader, 2003; Gillies, 2003; McCafferty et al., 2006; Cohen, 2014).

Teachers need to verbalize instructions related to CL as well, which results in fewer explanations later on. Teachers also need to think about the best process of giving feedback to groups, such as through group assessments, individual assessments, or dividing grades in two for half group and half individual work. An appropriate feedback method can help increase interactions and positive interdependence. Teachers need to monitor the learning of all their students and ensure that no learners have been staying back from groups. Monitoring all students can help teachers resolve initial problems so that the group interaction and cooperation dynamic later grows better.

Further, teachers need to consider that environmental factors (e.g., desks, chairs, and spaces for the teacher to pass through) are important to facilitating positive interdependence within groups (Azizinezhad et al., 2013; Koppenhaver \& Shrader, 2003; Gillies, 2003; McCafferty et al., 2006; Cohen, 2014). Therefore, students need to sit close together to allow meaningful interactions. A well-structured group guarantees that positive interdependence and promoted interactions take place. Moreover, teachers need to ensure that the assigned tasks warrant group work and are not just activities that students can complete independently. Thus, the concept of positive interdependence should be clearly explained to the students.

However, teachers should not ignore groups who struggle with completing tasks, as this could negatively affect the students and impart a feeling of failure. Continuous scaffolding between groups assists those who need help. Teachers also need to prevent the same set of students from working together in the same group for a long time. This may cause boredom and result in negative interdependence. Still, when students are not given enough time to form relationships while working together, it may negatively affect group work (Cohen, 2014; Birmingham \& McCord, 2004).

Teachers should bear in mind that it is not easy to use CL effectively. It may take a long time before they master effective CL use. CL may also be difficult for EFL students who are not familiar enough with each other to work cooperatively (McCafferty et al., 2006).

Table 1. Summary of the literature's suggested CL procedures

\begin{tabular}{|c|c|c|c|}
\hline CL environment & Forming groups in CL & CL tasks & Teacher's role in CL \\
\hline $\begin{array}{c}\text { Arrange the desks in the } \\
\text { classroom so students can face } \\
\text { each other (circle arrangement) }\end{array}$ & $\begin{array}{c}\text { The ideal group size ranges from } \\
\text { 2 to 3 members, and the } \\
\text { maximum is } 6 \text { members }\end{array}$ & $\begin{array}{c}\text { The academic task should have a } \\
\text { shared group goal }\end{array}$ & $\begin{array}{c}\text { Make the success criteria } \\
\text { explicit and link it to the } \\
\text { shared goal of completing the } \\
\text { CL task }\end{array}$ \\
\hline $\begin{array}{c}\text { Teacher can easily move } \\
\text { between groups and around the } \\
\text { classroom }\end{array}$ & $\begin{array}{c}\text { Different strategies can be } \\
\text { applied to randomly assign } \\
\text { group members, e.g., choosing } \\
\text { numbers }\end{array}$ & $\begin{array}{c}\text { Appropriate design of } \\
\text { meaningful tasks and careful } \\
\text { choice of task resources }\end{array}$ & $\begin{array}{c}\text { Scaffold and monitor the } \\
\text { learning process }\end{array}$ \\
\hline $\begin{array}{c}\text { Make all necessary resources } \\
\text { available on the desks in advance }\end{array}$ & $\begin{array}{c}\text { Form heterogenous groups } \\
\text { (different range of abilities in } \\
\text { each group) }\end{array}$ & $\begin{array}{c}\text { Be clear with the task } \\
\text { information }\end{array}$ & $\begin{array}{c}\text { Incorporate individual } \\
\text { accountability into the group } \\
\text { assessment }\end{array}$ \\
\hline $\begin{array}{c}\text { Limit CL resources to each group } \\
\text { and not to individuals }\end{array}$ & $\begin{array}{c}\text { Describe each student's role } \\
\text { requirements }\end{array}$ & $\begin{array}{c}\text { Evaluate the students' } \\
\text { Provide details about } \\
\text { completing the task } \\
\text { learning and provide useful } \\
\text { feedback }\end{array}$ \\
\hline $\begin{array}{c}\text { Create a less-threatening } \\
\text { environment }\end{array}$ & $\begin{array}{c}\text { Members evaluate how well } \\
\text { they carry out their specific } \\
\text { duties }\end{array}$ & $\begin{array}{c}\text { Provide only one copy for each } \\
\text { group }\end{array}$ & $\begin{array}{c}\text { Set time limits for the tasks } \\
\text { within the assignment }\end{array}$ \\
\hline
\end{tabular}




\section{Forming Groups in Cooperative Learning}

McCafferty et al. (2006) stated that there are many ways to form groups in CL. For instance, teachers can allow students to choose their own group members. This helps them feel more comfortable about their work. However, other researchers (Azizinezhad et al., 2013; Koppenhaver \& Shrader, 2003; Gillies, 2003; McCafferty et al., 2006; Cohen, 2014) warned that teachers need to avoid giving students opportunities for self-selection, as this could result in friendship groups, which are a distraction. Another method that can be applied for CL is grouping students based on their commonalities, such as those who like the same music, color, hobby, etc. Teachers can also form groups based on the different points of view held by the students. One other different way to organize a group is random selection, which is fast, easy, and fair. One final method of forming groups is the teacher's selection, which is recommended and could be more effective for organizing groups since it allows the EFL teacher specially to organize heterogeneous groups based on language proficiency. This can also help teachers promote peer tutoring.

However, Brookes and Grundy (1990) disagreed with this method of forming groups and suggested forming groups based on dissimilarities to have groups based on different abilities. Nevertheless, heterogeneous grouping remains an important issue in CL (Allan, 1991). Some research studies oppose mixing high and low achievers together, as some high-achieving students may feel bored and some low-achieving students intimidated. Johnson and Johnson (1998), meanwhile, have a different perspective: they indicated that high-achieving students could help other learners and themselves when they explain the information to them. Moreover, this can help high-achieving students develop many social skills, such as caring for others, acceptance, and belonging. They can also develop some academic skills, including rehearsal, elaboration, and memorizing. Many teachers confirmed these benefits for high-achieving students in McCafferty et al. (2006).

Still, in heterogeneous groups, high achievers always provide help and low achievers always receive help. Therefore, educators should encourage high achievers to model the task as well as complete the task itself, then help others complete the task instead of doing all their work for them. In this way, teacher monitoring and scaffolding with students supports the CL dynamic.

Previous research (Lou et al, 2001; Gillies, 2006; Gilles \& Boyle, 2010) found that small groups work best in the initial period while students develop their collaborative skills, while large groups help generate more interactions. Accordingly, in the beginning teachers should form small groups of students whose CL they can control gradually. However, some researchers (McCafferty et al., 2006; Kyndt et al, 2013) argued that forming large groups is better, particularly if students are working on complex tasks. These groups can share various ideas and knowledge. Thus, teachers should bear in mind that if they have large groups, the seating arrangement should be in a circle to facilitate observing CL, as it is easier for them to view the groups' dynamics in this way and interfere when students need help.

\section{The Positive Interdependence in Cooperative Learning}

Teachers play an important role in fostering CL and should spend some time explaining to students the importance of cooperating and working together. Additionally, they should help students realize that they can swim together to reach the end or sink together in the same place (Johnson \& Johnson, 1998). It is important for students to realize the importance of CL to help promote their positive interdependence.

McCafferty et al. (2006) offered two criteria to help students garner positive interdependence. The first indicates that students have to share the same goals or aims to complete a task. The second is to positively reward interdependence, which reflects the CL evaluation process. Teachers should create a suitable technique for group evaluation since this has a positive effect on students' work. However, even if teachers choose to offer reward-based group work, some problems may occur (Johnson \& Johnson, 2017). For instance, students who work better and harder than students who do not like participating much in group tasks will all get the same grade (Johnson \& Johnson, 2017). That may seem unfair to the students and could affect their positive interdependence. Therefore, teachers need to create a fair method to help students garner and retain positive interdependence.

Further, students' roles in positive interdependence could be an important issue in CL (Freeman, 1993; Siciliano, 2001; Gillies, 2006). Every student should have an important role, and there are many, such as facilitator (directing the group's work), observer of the group dynamic (checking that all students are working cooperatively), writer or recorder (writing down what the group has accomplished), and timekeeper (helps the group stick to deadlines and organizes and divides the tasks according to the specified time limit). McCafferty et al. (2006) believed that these roles should be rotated between group members to ensure students' CL and give every group member the opportunity to develop different skills based on the given role. This also helps low-achieving students take on non-academic roles, such as timekeeper, and prevents high-achieving students from controlling CL by constantly taking authoritative roles. By ensuring the rotation of roles between groups member, teachers can strike a balance between the students working in CL procedures.

Another feature that should be considered to ensure positive interdependence is resource interdependence. This relates to how students divide tasks between themselves to 
allow each group member to focus on one portion of the task, after which each member must share his knowledge with the other. The last important point that could promote positive interdependence is positive outside challenge interdependence. Teachers can conduct competitions between groups to reflect positively on CL (McCafferty et al., 2006), including providing prize or positive points to help the students achieve their best. However, teachers should be careful when conducting competitions since they can result in negative student behavior (Johnson \& Johnson, 2017).

\section{The Present Study}

Applying CL is an effective strategy to help EFL students use their target language in the classroom and create a meaningful learning environment. However, previous researchers stated that EFL teachers in Saudi Arabia encourage CL by using group work as a more formal arrangement strategy in their classroom, which may not encourage or increase group interactions and result in a negotiation of meaning (Mohammad, 2014; Alghamdi \& Gillies, 2013; Alharbi, 2008). This is because EFL classrooms may lack to suitable procedures to promote CL interactions. Some previous studies explored the benefits and difficulties of EFL group work, concluding that students were not aware of their roles when working in groups. Moreover, they found that many students were not willing to share knowledge since no one discussed their knowledge and were only willing to answer the teachers. These extant studies further explored the issue of learners' lack of awareness about the suitable and effective group dynamic needed to create CL. Therefore, there is a need for a study concerning the procedures used to apply CL by EFL teachers. This study thus explores EFL teachers' behaviors and perceptions regarding the application of appropriate CL procedures, as recommended by extant literature (see Table 1). This study is important because it can help EFL teachers apply CL more effectively. The study answers the following research questions:

1. How do teachers use the recommended procedures to create CL in their lessons?

2. How do the teachers' perceptions of the recommended procedures affect their CL lessons?

\section{Methodology}

In the current study, the researcher employed a mixed-methods research design to explore the teachers' behaviors and perceptions about applying the recommended CL procedures. The researcher proved the validity and reliability of the content written for the procedures as well as for all used methods, through sending them to the experts in the field. Then, Specifically, the researcher recommended appropriate CL procedures for the nine participating teachers to apply in their daily teaching practices. Mixed methods were applied as follows: structured observations of EFL lessons, teachers' daily reports, and a teacher open-ended questionnaire. This research paper used a purposive sampling technique to select nine female EFL teachers, in selected secondary schools at Makkah City. The participants' age range was 24-30 years old, while their experiences varied from 1 to 6 years.

When the nine teachers agreed to take part in the study, the researcher handed out a copy of the procedures and instructions for applying CL (see Appendix 1). Additionally, the researcher gave the teachers a copy of the main information that they should include in their daily reports (see Appendix 2). The teachers could fill in their daily reports after their EFL lessons to reflect on and write their perceptions on applying the recommended procedures and how it worked for them. The researcher also visited one lesson per each participating teacher to record their behaviors while applying the recommended procedures (for a copy of the observation sheet, see Appendix 3). The type of data applied to the observations was semi-quantitative, meaning that the researcher's focus was exploring the number of teachers who frequently applied each CL procedure and instruction. In the last research method, the researcher distributed a questionnaire to the participating teachers that included only open-ended questions which focused on the four key aspects of applying CL (see Appendix 4). The teachers filled out the questionnaires at the end of the term after they applied the CL procedures over several lessons.

The researcher then analyzed the data obtained from the participants using Microsoft Excel for quantitative purposes and a thematic analysis for qualitative purposes to answer the research questions and reach the present study's objectives. The thematic analysis helped the researcher highlight the main themes that emerged from the data. To manage the data, all the teachers' responses were categorized into four themes that detailed the teachers' behaviors and perceptions.

\section{The Analysis Process}

For the structured observations, the researcher used Excel to count the number of teachers who applied, sometimes applied, or did not apply the recommended procedures. Then, the researcher summarized the frequency of each procedure's item in a corresponding table for a total of four tables.

The researcher also thematically analyzed the data from the reports and open-ended questionnaires. During the initial process, the researcher read the data many times to gain familiarity with the content (familiarization). To describe the main themes, the researcher generated codes from the data, then classified them into relevant themes, main themes, and subthemes. Dörnyei (2007) suggested the use of several stages to interpret qualitative data. Generally, these stages include transcribing the data, initial 
coding, grouping the initial coding, searching for themes, defining and naming themes, and writing the report.

\section{Findings}

This section highlights the main themes that emerged from the data as related to teacher behaviors and perceptions about applying the CL procedures, which are the $\mathrm{CL}$ educational environment, forming groups in $\mathrm{CL}$, CL tasks, and the teacher's role in and reflections on CL. The researcher analyzed and discussed all presented data in relation to the application of the CL procedures and instructions. Accordingly, this section first presents the results of the quantitative structured observation, then follows with the qualitative results from the daily reports and open-ended questionnaire. The researcher considered the observation results based on the frequency of each procedure's application, as these frequencies reflect the teachers' behaviors, while the qualitative data reflects the teachers' perceptions. Figure 1 identifies the themes that emerged from the data, and the remainder of the section presents an in-depth analysis of these themes.

\section{The Cooperative Learning Educational Environment}

The most interesting finding from the observations, as outlined in Chart 1, is that most of the teachers ( 8 out of 9) prepared their CL resources for the groups and not for individual students. Moreover, a majority of the teachers (6 out of 9) made all the necessary resources available in advance on the students' desks. The same number of teachers arranged the desks appropriately for CL in the classroom to help them move easily between groups. It appears that the participating teachers prepared the classroom in a well-organized manner for CL; however, they did not prepare a fully safe environment for the students' CL interactions and communications.

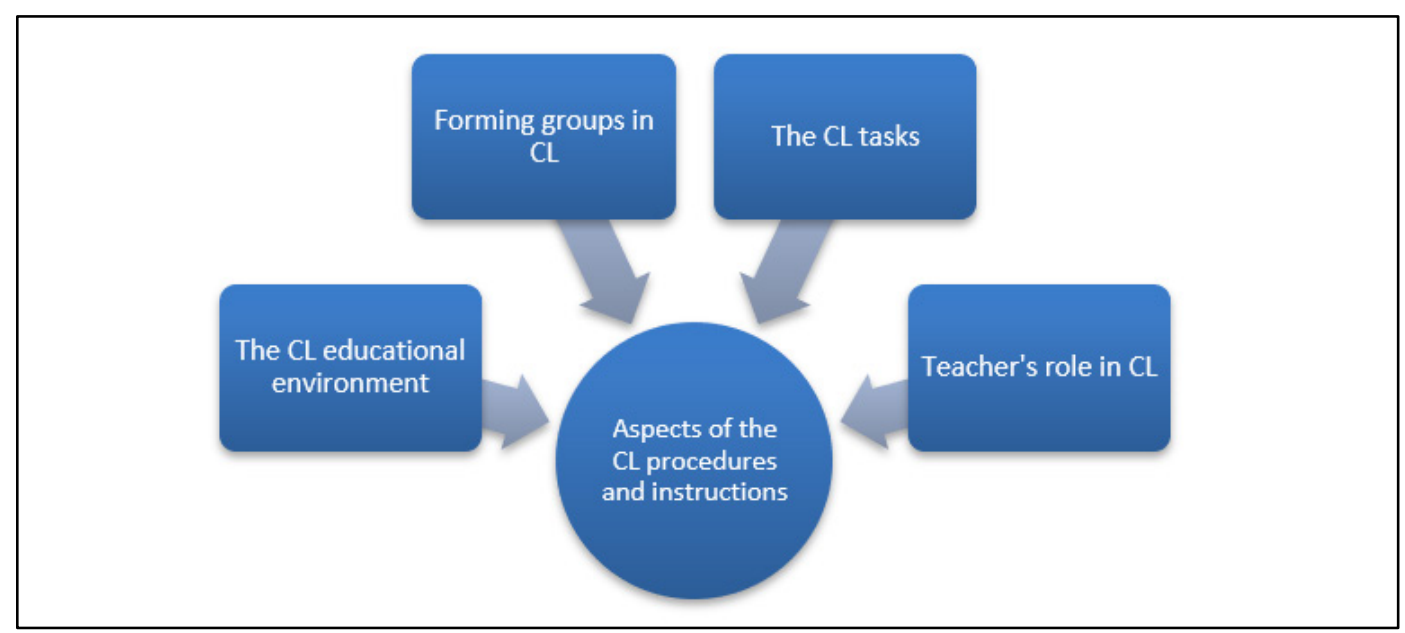

Figure 1. The themes that emerged from the findings

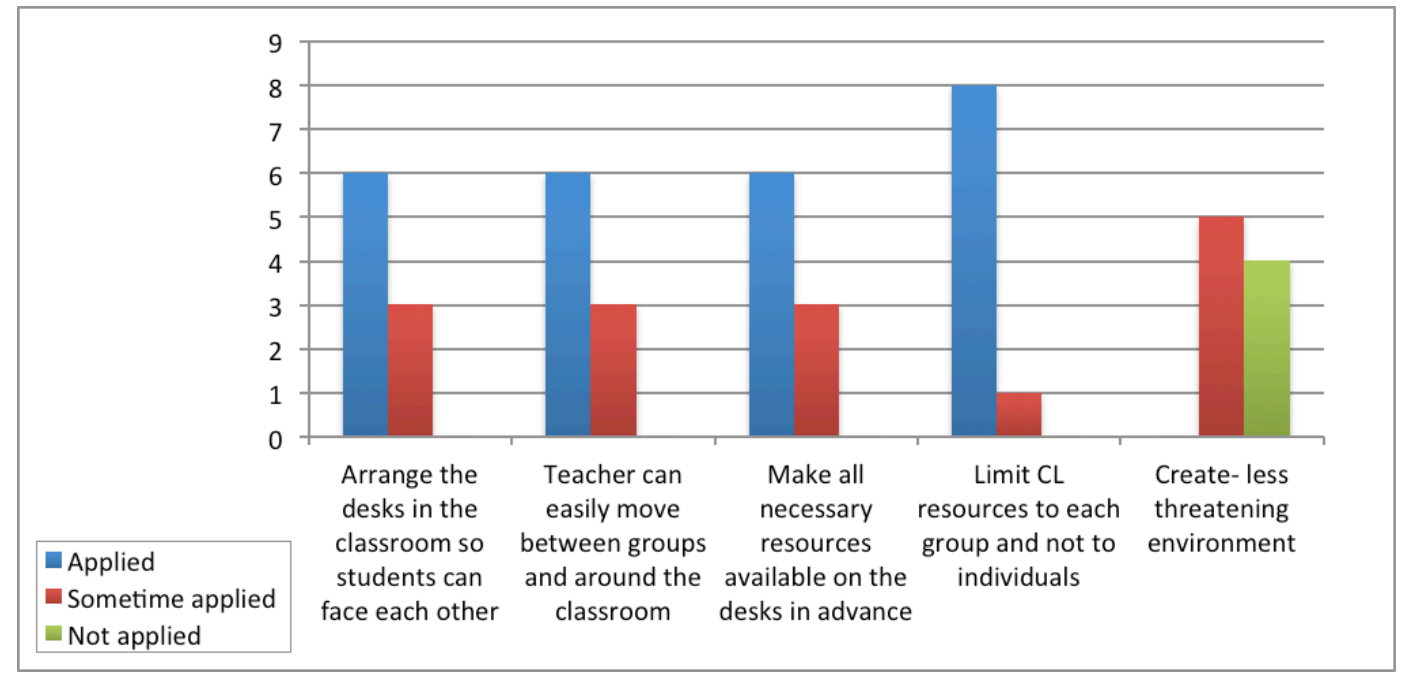

Chart 1. The utilization of the instructions for the CL educational environment 
The thematic qualitative data results explain that most of the EFL teachers perceived that they organized the desks in the classroom to help apply CL. However, they struggled with the desk arrangement since every student has an individual desk; as such, it was sometimes difficult to cluster the desks together to ensure that the students faced each other while communicating. In CL, it is appropriate to make enough spaces between groups to enable teachers to move between them. The results show that the teachers who organized the desks well found enough space to walk between groups for monitoring and scaffolding.

Further, the findings show that the EFL teachers struggled with preparing the materials in advance and placing them on the desks because the classrooms that they taught in were not specific to EFL learning. Rather, the students study different subjects and have various lessons before their EFL class; therefore, there was insufficient time for many teachers to prepare the resources on the desks in advance. Thus, the teachers tried to dedicate the first five minutes of the EFL class to preparing for the lesson.

Another interesting finding is that all the teachers perceived that to help learners interact and share the activities, they should have only one copy of the required task that they must then complete together. The teachers felt that having a shared copy could reflect positively on the students' interactions and dependence, while providing the groups' multiple copies could reflect negatively on the students' communication.

Nevertheless, the teachers said that the students were sometimes unwilling to follow the grouping instructions, as they liked to sit next to their friends. Therefore, the teachers faced some negative behaviors from certain students if they were forced to follow the CL procedures, though some of the teachers explained that the students started to accept and follow the procedures later in the class. As Teacher 9 stated:

"I was struggling because sometimes students refused to listen to me at the beginning of the class, but they changed their mind later. Even so, some students kept refusing my instructions the entire time; although they listened to me, the cooperation between them and their classmates was still not very good."

\section{Forming groups in cooperative learning}

The most prevalent finding from the observations is that all the participating teachers formed an ideal number (3-6) of group members for CL. Most of the teachers (6 out of 9) also formed heterogeneous groups. Still, only 3 of the participating teachers used a random mode of assigning groups. A majority of the teachers (7 out of 9) did not explain each student's role requirements. Chart 2 summarizes these results.

From this study's qualitative data, 5 teachers stated that they were used to dividing the students into groups based on their abilities, as they believed that each group should be a mix of high- and low-achieving learners to ensure that all students in the class are supported and understand all the information in the lesson. These teachers seemed to be very careful about reflecting positively on the learners, even though there are differences between them in terms of knowledge and skill level. Therefore, some teachers stated that heterogeneous groups can help learners increase their CL interactions because high-achieving learners can work as teachers for low-achieving learners. By doing so, the teachers open space for different levels of learners to promote interactions.

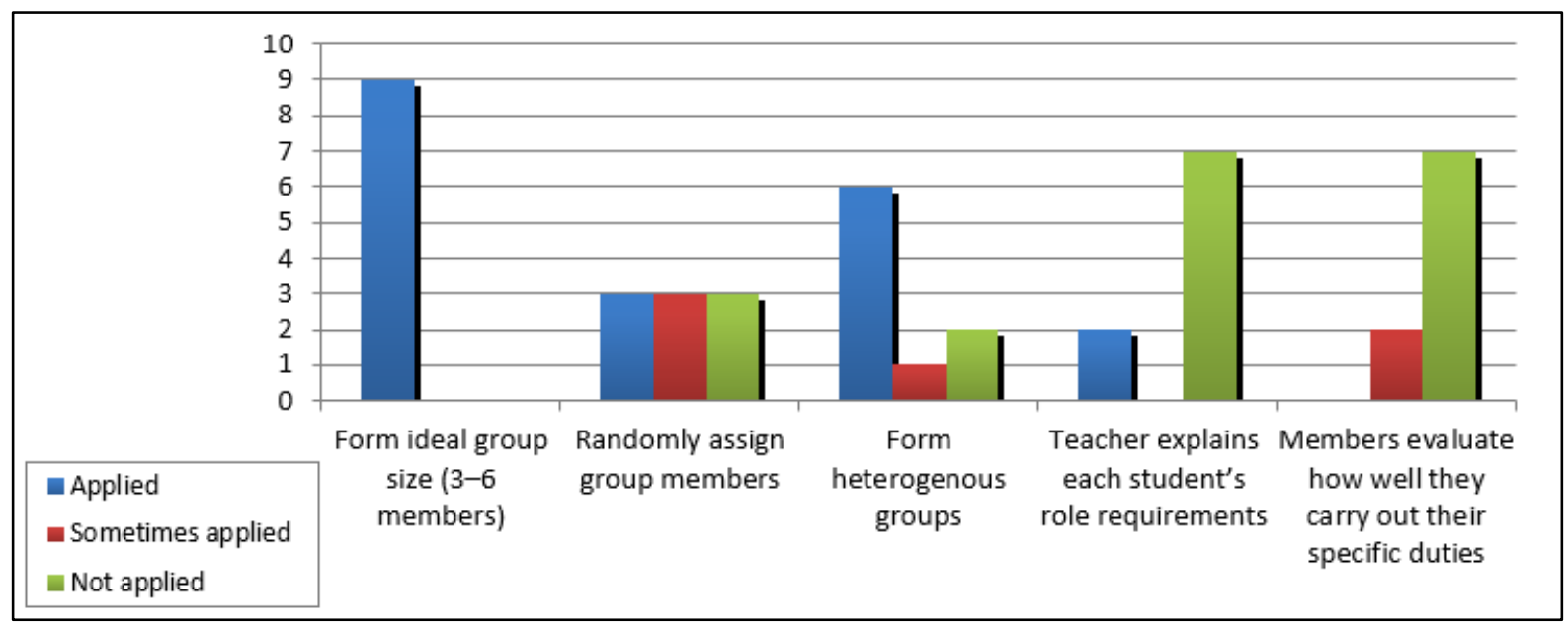

Chart 2. The utilization of the instructions for CL group formation 
Another way of classifying groups is based on the students' common interests, such as favorite color. Some teachers indicated that this helps the students share their interests. The teachers also explained how similar characteristics can help learners increase their cooperation owing to the fact that they have something in common to talk about, especially if the task requires sharing their opinions. As Teacher 2 told:

"I used to form groups based on their favorite color because I believe students who have chosen the same color could have similar characteristics that help them interact more to complete tasks in groups."

Two teachers used a different method for classifying groups: they first selected group leaders and then allowed the leaders to choose their fellow group members. These teachers believed that the leaders were the main members of the groups and would control and help their group interact and create CL.

Meanwhile, some of the EFL teachers reported that they preferred classifying groups based on the students' desk placements. These teachers explained that this organization technique saved time for the lesson, as the students would not change their places; moreover, it would be more comfortable for the students to work with those next to them. Similarly, some teachers stated that they used the students' name list to shorten the time for group formation and because they believed it to be the fastest method for organizing groups.

One negative finding related to group dynamic is that many teachers indicated that the students did not seem willing to take a suitable role while working in CL groups. Therefore, the teachers followed certain techniques to promote the learners' motivation. Some of the teachers encouraged their students by mentioning the advantages of CL, while others wrote the groups' instructions on the board and encouraged the students to follow them. Further, some teachers stated that they read and explained the instructions, or otherwise repeated the instructions to students to remind them of the procedures. After they ensured that the students understood the CL procedures, the teachers then explained the different roles to them, encouraged each member to take a role and divide the tasks between themselves, and spoke with them at the end of the lesson to make sure that they were doing well.

\section{Tasks applied in cooperative learning}

As featured in Chart 3, an interesting finding from the CL task procedure is that the majority of teachers (6 out of 9) used tasks that reflected a shared group goal on the learners. Additionally, most of the participating teachers ( 8 out of 9) provided only one copy of the task to each group. Only a few teachers ( 3 out of 9) provided details about completing the task and included the designated time for each task. The findings also explain that 5 teachers applied an appropriate design for meaningful tasks, while 4 teachers sometimes offered a meaningful task design. Four teachers were clear about the information regarding the task, though 3 were clear only about some of the details of the provided task; 2 teachers were not at all clear about the task information.

The qualitative data findings show that a majority of the teachers liked to use brainstorming and mind-mapping tasks to help learners interact to complete the task. According to these teachers, these kinds of tasks help learners share their knowledge. Brainstorming especially helps EFL learners generate as many ideas as they have, discuss them, and write them down. Mind-mapping also helps learners correlate their ideas to form new knowledge or connect old knowledge with new knowledge.

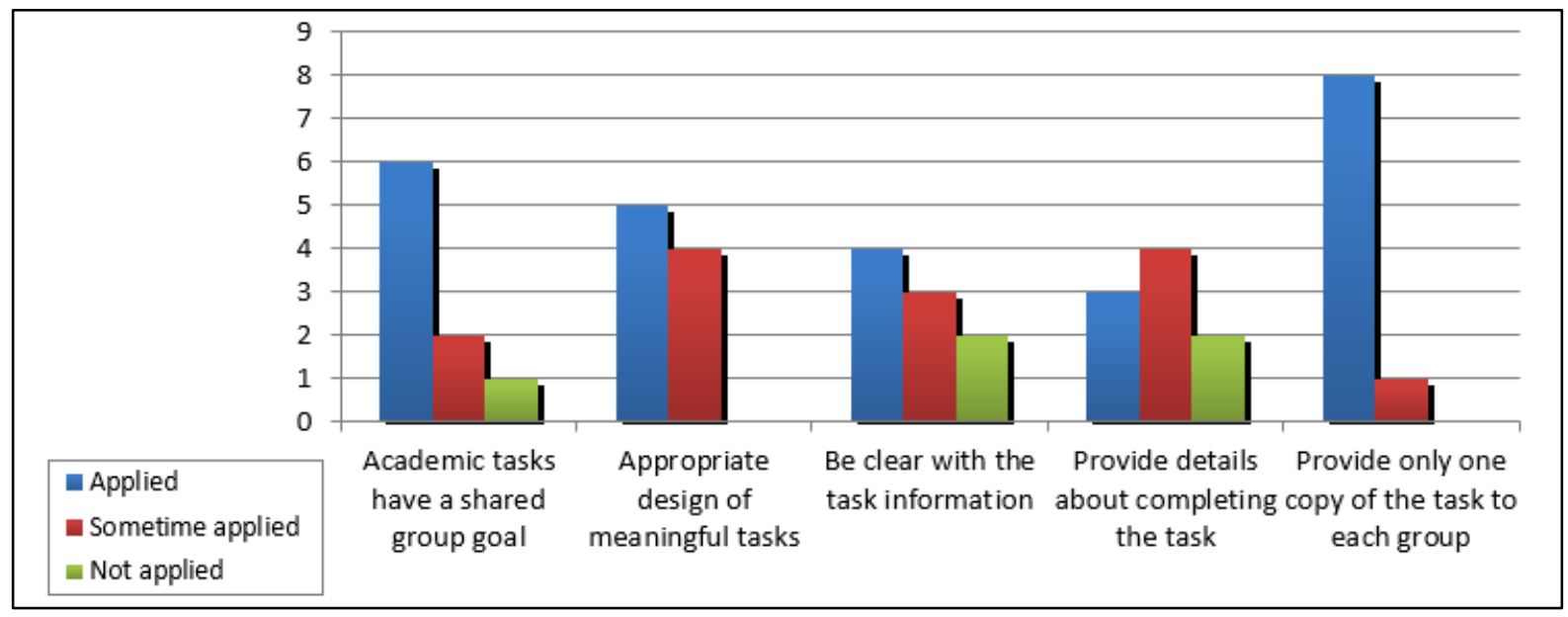

Chart 3. The utilization of the instructions for the applied CL tasks 
Another task type that some teachers provided were gaming tasks, such as completing puzzles and matching cards. They believed that this kind of task would help learners enjoy learning and, in this way, increase their interactions with others. Further, a majority of the teachers stated that they assigned the learners all kinds of tasks for all language skills, such as pre-reading comprehension, grammar, vocabulary, reading, and writing tasks. They explained that students could achieve all tasks together, and different activities are suitable for CL since students learn better in practice and can apply their knowledge with others better than in individual learning.

Other teachers preferred to instead focus on visual tasks to help their learners interact and share their ideas by explaining the pictures. Such teachers claimed that visual tasks helped learners take on effective roles in the task because images and pictures are easier means for them to start a discussion. On the other hand, only a few teachers stated that a discussion task is the most suitable for increasing group cooperation, as it opens chances for learners to speak and discuss and share knowledge. For example, Teacher 7 said:

"I like to focus on visual tasks to help learners interact and discuss and share their ideas during the lessons."

Another useful procedure some of the teachers conducted was starting with an easy task at the beginning of the lesson before moving on to a more challenging task to help the group members gradually take on effective roles and easily work with each other. This is considered a meaningful task since it enables learners to make meaning of the provided task.

\section{Teachers' roles and reflections in the cooperative learning procedures}

According to the observations from this study, only some of the teachers (4 out of 9) were clear about the group work's success criteria and their link to the required task's shared goal. The findings specify that only 2 of the participating teachers took an effective role in CL by scaffolding and monitoring the learning process and that most teachers (6 out of 9) did not take an effective role at all (see Chart 4). Another negative finding is that none of the teachers fully incorporated individual accountability into the groups' task assessments. Only a few teachers evaluated the students' learning during CL, and not many were very organized about setting a suitable time for each task.

From the qualitative findings, many of the participating EFL teachers used common techniques to help learners apply the CL procedures, such as creating competition between groupings. As Teacher 6 reported:

"I encourage cooperation between group members by holding a vote for the best cooperative member in the group, and then I give a treat or bonus to groups who make revisions together to reach the appropriate answers and check how everything is going with their work."

This teacher encouraged learners to make revisions and take an effective role by checking the members' answers through CL. Such teachers use motivational techniques to help learners take on an effective role; the most common of these techniques as used by EFL teachers are giving bonuses and small treats and taking 5-minute breaks during the lesson.

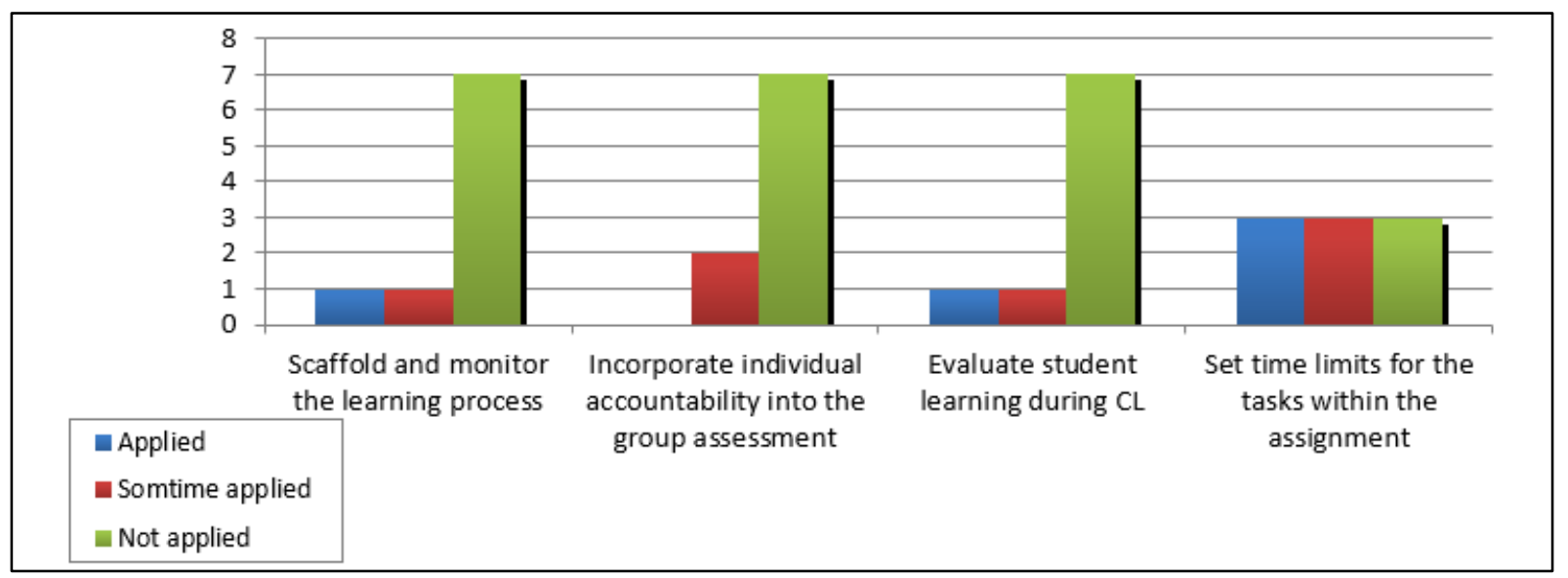

Chart 4. The utilization of the instructions for the teachers' roles in CL 
All the participating teachers believed that the CL procedures and instructions helped them organize their EFL lessons. They also stated that their students' interactions in CL increased. Additionally, the teachers reported that the grouping procedures helped them evaluate their students, as it clarified how they had to monitor learners. Thus, they could help learners who needed help with completing the tasks.

On the other hand, some teachers said that it was difficult for them to apply the CL procedures, though others explained that applying the procedures got easier with time. Specifically, some teachers said that they found the procedures difficult to apply since certain students refused to be distributed randomly, though over time, the teachers discovered that the CL procedures were better for their students, since the students ended up helping each other, particularly with high-achieving students assisting low-achieving students.

The teachers did note negative behaviors between students when applying the CL procedures in earlier lessons, such as when learners tried to prove to everyone that they wanted to be better than the others; however, these negative behaviors did decrease, and the students exhibited positive behaviors toward each other and cooperated well after learning to enjoy it. Teacher 7 even stated:

"When I applied the procedures in the earlier lesson, there were some negative behaviors between students, such as them trying to prove to everyone that they wanted to be better than the others, but with time the negative behavior started to decrease, and the students showed positive behaviors toward each other and started to cooperate well since they enjoyed it."

Some teachers stated that the CL procedures helped them be clear in their lessons and saved time for the lesson itself, as it was enough to complete all tasks and increase the learners' interactions. However, they complained about the noise resulting from $\mathrm{CL}$.

Many teachers found that the procedures were good in forming effective groups and reflecting positively on CL. The teachers also stated that the procedures helped them give chances for all students to participate in the lesson. The procedures helped ensure the students' accountability by giving them specific roles, which helped them exhibit positive behaviors in their groups. Further, it helped the teachers monitor and check the students' learning. As Teacher 6 noted:

"The procedures facilitate students' interactions and participation since every member takes a role in the group and it helps their social skills improve. It helps groups to be independent, and it also helps the teachers monitor and check the students' learning. Also, the procedures help ensure the students' accountability by giving them specific roles, and they help learners exhibit positive behavior in groups, such as listening to others when they are talking and

\section{taking turns to speak."}

In general, the teachers said that the students positively reflected on the group instructions, as it helped increase their interactions and participation. Some teachers stated that the procedures and instructions helped promote the students' interactions and developed their communication skills; they also helped improve the students' self-esteem. The procedures ultimately encouraged the learners to take responsibility and find more than one solution to the tasks.

\section{Discussion}

The main findings related to the CL environment aspect show that a majority of teachers arranged the students' desks appropriately for $\mathrm{CL}$ in the classroom, as this helped them move easily between groups. However, some teachers explained that they struggled with the desk arrangement because every student had an individual desk; as such, it was sometimes difficult to cluster the desks together to ensure that the students faced each other. For CL, it is appropriate to make enough space between each group to enable teachers to move around them.

The goal of CL in EFL learning is to get students to use the target language to communicate and build their knowledge, and environmental issues have a major effect on CL's success. From the literature, teachers' environment procedures are as follows: arranging the classroom desks so students face each other, having the teacher be an effective facilitator, moving easily around the classroom, and organizing the desks to minimize disruption to other groups. Applying these procedures has many benefits that can facilitate interaction and allow teachers to monitor students' learning. Moreover, they help students concentrate on their work while preventing wasted time.

This study's findings identify that the teachers perceived how some students were unwilling to follow grouping instructions because they liked to sit next to their friends. Previous literature demonstrated that students do not have the knowledge or skills to help them work effectively in groups (Shimazone \& Aldrich, 2010). Since it is important to practice English skills in authentic environments, CL can help students work effectively in groups. Thus, CL supports instructional differentiation, wherein students of different English comprehension levels can support and learn from one another. When used in supportive and encouraging learning environments, group activities promote the use of all language development components without forcing students to step too far out of their comfort zones.

The previous literature clarified different methods that EFL teachers applied to form groups in CL. Hassaskhah and Mozaffari (2015) conducted a study to prove that group composition can affect CL. They particularly focused on two types of group formation: student-selected groups and teachers-assigned groups. With the first type, the students could form surely selected groups, and they 
normally chose their friends to work with.

This present study's findings further explain how some participating teachers used different methods to form groups: for instance, they selected group leaders and allowed those leaders to choose the remaining group members, as they believed the leaders to be the main members in the group who would control and help their group interact and create CL. These results are in line with those from extant research (Chapman et al., 2006; Hilton \& Philips, 2008), which also found that when students were allowed to form groups, they usually chose their friends, whom they felt comfortable communicating with (Chapman et al., 2006; Russell, 2010).

Some of this study's results indicate that the EFL teachers preferred forming groups based on the students' desk placement. The teachers explained that this organization technique saved lesson time, as the students would not change their places, and made the learners more comfortable because they were working with the students next to them. Similarly, a few teachers stated that they used the students' name list to shorten the time for forming groups and because they believed it was the fastest method for organizing groups. However, teachers need to bear in mind that a well-structured group should ensure that positive interdependence and promoted interactions do actually take place (McCafferty et al., 2006).

The findings additionally explain that some teachers classified students into groups based on their abilities. Some teachers even stated that heterogenous groups can help learners increase their CL interactions because high-achieving learners could work as teachers for low-achieving learners. The findings also show that the teachers formed groups based on the students' common interests, such as their favorite color. These results seem to be in line with previous literature that described that in teacher-selected groups, students engage in more effective CL. Many researchers also reported that learners prefer and like to work with more focus on tasks to achieve better outcomes (Hilton \& Philips, 2008; Mitchell et al., 2004).

Although the student-selected group formation method is preferred, previous research found that the close relationships between learners could reflect negatively on students' learning (Hilton \& Philips, 2008; Mitchell et al., 2004). Moreover, this could result in less improvement in the learners' social skills and cause the formation of homogeneous groups that struggle to develop skills (Oakley et al., 2004). Researchers also criticized student-selected groups by claiming they lack orientation, mostly because pre-existing friendships among group partners tend to cause them to spend more time talking than focusing on the task (Chapman et al., 2006; Hilton \& Philips, 2008; Mitchell et al., 2004; Shindler, 2010).

Previous studies identified that the achievement of group work varies between the two group formations (student-selected and teacher-selected; Bachman, 2010;
Dillon \& Cheney, 2009; Oakley et al., 2004). These studies conducted experimental research and concluded that teacher-selected groups outperform student-selected groups. The EFL literature also stated that teachers need to realize that there are many behaviors they have to avoid while utilizing group work in classrooms. For example, student self-selection could result in friendship groups that cause distractions. Teachers thus need to occasionally shuffle group members, as working together for too long could result in boredom; however, teachers should also give learners appropriate and sufficient time to form relationships before they start working on the task. On the other hand, some studies such as Mushtaq et al. (2012) and Mahenthiran and Rouse (2000) analyzed which group composition performed better and found that student-selected groups perform better than teacher-selected groups.

This study's findings demonstrate that many of the participating teachers formed heterogenous CL groups. Previous researchers defended the positive effects of heterogenous CL groups, for it is beneficial to have mixed abilities in each group to allow students with high abilities to help those with low abilities (Roberts, 2016; McCafferty et al., 2006). This study's findings thus seem to be in line with existing studies that claimed that consideration should be given to group composition; it was also acknowledged from previous studies (McCafferty et al., 2006) that a mix of academic ability and learning styles is the most desirable in a group.

Likewise, the most important group procedure is group size, which should not exceed six members; three to four students in each group is more effective, as large groups can make it difficult for students to contribute effectively. Additional studies agreed that small groups work best in the initial group formation period whiles students develop their collaborative skills (Roberts, 2016; McCafferty et al., 2006).

Another interesting finding is that the majority of teachers used tasks that reflected a shared group goal on the learners. Further, most of the participating teachers provided only one copy of the task to each group. Previous literature recommended that tasks must have an academic objective and shared group goal, and it is important for the tasks to ensure group work and not be something students can do individually. Positive interdependence should be clearly explained to the class as well, and providing written instructions for each group is also beneficial. Additionally, Asgarika (2014) explored the differences in the effects of learners' competences and outcomes between structured and non-structured tasks, finding that structured tasks have higher mean scores than non-structured tasks. However, there were no differences between them regarding outcome accuracy.

This study's findings highlight a common method many of the teachers used, which is starting with an easy task and then moving on to more challenging tasks to help groups gradually develop effective roles and easily work 
with each other. This is considered a meaningful task; related, previous studies recommended designing meaningful tasks (Robinson, 2011; Gagné \& Parks, 2013) because these provide useful feedback, promote thinking, enhance negotiation, and facilitate meaning comprehension. Willis (1996) proposed using specifically the Task based Learning in CL, since it introduces learners to the topic through pre-task work, following which learners can complete the main task cooperatively. After these learners give feedback to other students, they can also conclude the task.

The academic tasks should also have a shared goal. Teachers should make it clear that group success depends on the students' cooperation (Robinson, 2011; Gagné \& Parks, 2013). Teachers should, moreover, incorporate individual accountability into the group's assessment, as well as provide written details and supportive instructions. These guidelines will help teachers develop their students' responsibility for each other's success, which could help the students understand the task and goal and also prevent them from depending too much on others. Further, it can also reduce the need for teachers' interventions during the task.

The findings outline that a majority of teachers liked using brainstorming and mind-mapping tasks to help learners interact while completing the task. According to the teachers, these tasks help learners share knowledge together. Especially brainstorming helps EFL learners generate as many ideas as they have, discuss them, and write them down. Mind-mapping further helps learners correlate ideas together to form new knowledge or connect old knowledge with new knowledge. This finding seems to be in line with Adewuya (2003), who found that brainstorming tasks can open opportunities for students to express their opinions and give them a chance to explore new knowledge about themselves.

Stephen and Stephen (2005) highlighted that discussion tasks can help learners go through the process of interaction to achieve mutual understanding among group members. Additionally, many researchers (Abdu-Raheem, 2011; Yusuf \& Al-Banawi, 2013; Ryoo, 2010) confirmed that providing discussion tasks can help activate learners' engagement in the thinking process and enhance their social skills. These researchers also confirmed that discussions help promote the desire to learn. Further, they stated that in a discussion task, learners do not need to provide evidence or exact answers, as they are included in different perspectives. Thus, learners can enhance their thinking skills by working together in a discussion task. These results comply with previous literature, as some researchers (Gage \& Berliner, 2002; Iman \& Ingirani, 2019) stated that discussion tasks can help learners improve their democratic and reasoning skills, as well as their learning. Therefore, EFL teachers should provide discussion tasks when teaching oral skills for CL (Iman \& Ingirani, 2019).

Another interesting finding emerged after some teachers reported using gaming tasks, such as completing puzzles and organizing cards. They believed these tasks help learners enjoy learning and increase their interaction with others. This finding agrees with a previous study that compared teaching EFL using traditional methods and using game methods (Alghamdy, 2018). The study found that games are important for teaching EFL through interactions and increase students' communication in learning, thereby making them successful learners (Alghamdy, 2018). It also found that games encourage learners to work together rather than individually. Similarly, the study noted that games increase learners' motivation and interaction, meaning games can improve EFL practices in CL (Alghamdy, 2018).

This study's findings show that many students did not seem willing to take a suitable role while working in CL groups. Often, students come to school with no or few ideas about their role in CL, so they are not aware of the suitable roles they can take (Shimazone \& Aldrich, 2010). By applying facilitating strategies and suitable procedures, teachers can help students work positively in CL: for example, identifying different roles for each member, such as a recorder, manager, reporter, etc., can promote interdependence among group members. Teachers ultimately need to explain why and how students can complete the activity.

The CL literature stated that teachers need to provide descriptions of each student's role requirement in the group. Teachers also need to monitor the groups' performance per these separate roles and provide feedback; moreover, the teachers need to encourage the group members to take care of each other, check that they all reach suitable understanding, and complete the task together. Specifying each member's roles can help the students reflect on their roles and encourage interdependence in the groups while ensuring individual accountability.

Similarly, the study's findings explain that the teachers used some motivational techniques to help learners take on an effective role; the most common techniques were giving bonuses or small treats and taking 5-minute breaks during the lesson. McCafferty et al. (2006) similarly defended the importance of positive reward interdependence, which reflects the CL evaluation process. Therefore, teachers should create a suitable technique for group evaluation, as this positively affects the students' work.

The EFL literature proposed that teachers need to follow some techniques to promote and foster learners' CL interactions. They also need to explain why and how students completed the activities. Therefore, students need to be aware of the content knowledge and skills to help them learn and practice new skills (Barkley et al., 2014). Teachers should accordingly focus on the rationale behind the students' answers to enhance discussions between group members.

Furthermore, teachers need to be facilitators and active 
listeners during group activities. They need to go around the room and listen to students' discussions without interfering or participating. Teachers need to keep notes and record common mistakes. When students struggle with assignments, teachers should stop and provide help. They should similarly bring the groups back together as a class to summarize the activity's results and use previous group observations to determine which ones they should ask to report their results.

Although some teachers struggled to apply the CL procedures in their lessons, they explained that applying the procedures got easier with time. Additionally, some teachers said they found them difficult to apply since students refused to be distributed randomly; however, the random allocation helped students become aware of the expectation to work with others. The teachers also explained that their experience after applying CL was better for the students since they helped each other, particularly with high-achieving students helping low-achieving students. From the CL literature, some researchers indicated that EFL teachers attended training courses for CL implementation, but after a few months or a year, they still struggled with CL implementation (McCafferty et al., 2006). The most popular reason behind this issue the teachers gave is that preparing the lesson consumes too much time in CL. McCafferty et al (2006) claimed a solution for this problem is collaboration between EFL teachers. Thus, teachers who teach similar lessons can share materials, which would also enhance each other's performance. They could additionally attend each other's classes and record their feedback regarding their colleagues' CL implementation.

From this study's findings, the participating teachers said that the CL procedures helped them evaluate their students, as the procedures made it clear how to monitor learners. Similarly, according to the procedures, teachers should not ignore students who cannot work well in groups and rather need to support, scaffold, and help students complete the task together. As such, teachers need to monitor groups while working to support and help resolve problems that could emerge from negative behaviors. Teachers also need to designate time for reflection and feedback, as well as acknowledge progress made and good group behavior. This can develop appropriate behaviors that should exist in group work, such as taking turns to speak, active listening, and determining behavior that should continue or change. This study recommends that teachers ask a group spokesperson to explain the group's reasoning behind its response. Teachers also need to promote participation by asking other groups to respond as well and ask questions to help students connect and understand the ideas presented during the discussions. Finally, the findings suggest that the instructions for applying CL could help EFL teacher to be a facilitator rather than a presenter in the EFL classroom. Also, the study recommends that EFL learners taking the main role: negotiating, discussing, completing the task in the classroom. This study could be useful for EFL teachers to use the instructions of applying CL as a guide to promote and enhance implementing cooperative Environment in EFL classroom. Thus, this study recommend further researches related to the EFL teacher's role, and EFL learner's role in Cooperative Environment.

\section{Appendix 1}

The procedures and instructions for applying cooperative learning $(C L)$ in groups

\section{Dear EFL Teacher,}

In this document, I outline the suitable procedures from the literature for applying CL that I would like you to utilize in your EFL lessons.

\section{A Brief introduction to CL in EFL classrooms}

It is essential to apply CL in EFL classrooms, as it opens chances for learners to communicate and interact using the target language; therefore, they achieve the aims of studying the language.

To apply CL, we need to divide the students into suitable groups and allow them to attain the required knowledge through their interactions with other learners. Additionally, to ensure that the groups work well, we need to apply suitable procedures to enhance the effectiveness of CL. We also need to ensure that the environment is suitable for CL. Further, we need to form well-structured groups to help the learners interact successfully. The tasks used in CL affect and reflect on learners' work as well. The last and main procedure is to certify that you as the teacher work well and assume an effective role during CL.

The table below highlights the main procedures for each of these aspects; as an English language teacher, you need to be sure that you apply each one as outlined in this table. 


\begin{tabular}{|c|c|c|c|}
\hline CL environment & CL group formation & CL tasks & Teacher's roles in CL \\
\hline $\begin{array}{l}\text { Arrange the desks in the } \\
\text { classroom so students can face } \\
\text { each other (circle arrangement) }\end{array}$ & $\begin{array}{c}\text { The ideal group size ranges from } 2 \text { to } \\
3 \text { members, and the maximum is } 6 \\
\text { members }\end{array}$ & $\begin{array}{l}\text { The academic task should have a } \\
\text { shared group goal }\end{array}$ & $\begin{array}{l}\text { Make the success criteria explicit } \\
\text { and link it to the shared goal of } \\
\text { completing the CL task }\end{array}$ \\
\hline $\begin{array}{l}\text { Teacher can easily move between } \\
\text { groups and around the classroom }\end{array}$ & $\begin{array}{c}\text { Different strategies can be applied to } \\
\text { randomly assign group members, } \\
\text { e.g., choosing numbers }\end{array}$ & $\begin{array}{c}\text { Appropriate design of } \\
\text { meaningful tasks and careful } \\
\text { choice of task resources }\end{array}$ & $\begin{array}{l}\text { Scaffold and monitor the } \\
\text { learning process }\end{array}$ \\
\hline $\begin{array}{l}\text { Make all necessary resources } \\
\text { available on the desks in advance }\end{array}$ & $\begin{array}{l}\text { Form heterogenous groups (different } \\
\text { range of abilities in each group) }\end{array}$ & $\begin{array}{l}\text { Be clear with the task } \\
\text { information }\end{array}$ & $\begin{array}{c}\text { Incorporate individual } \\
\text { accountability into the group } \\
\text { assessment }\end{array}$ \\
\hline $\begin{array}{l}\text { Limit CL resources to each group } \\
\text { and not to individuals }\end{array}$ & $\begin{array}{c}\text { Describe each student's role } \\
\text { requirement }\end{array}$ & $\begin{array}{l}\text { Provide details about completing } \\
\text { the task }\end{array}$ & $\begin{array}{l}\text { Evaluate the students' learning } \\
\text { and provide useful feedback }\end{array}$ \\
\hline $\begin{array}{c}\text { Create a less-threatening } \\
\text { environment }\end{array}$ & $\begin{array}{l}\text { Members evaluate how well they } \\
\text { carry out their specific duties }\end{array}$ & $\begin{array}{l}\text { Provide only one copy for each } \\
\text { group }\end{array}$ & $\begin{array}{c}\text { Set time limits for the tasks } \\
\text { within the assignment }\end{array}$ \\
\hline CL environment & Forming groups in CL & CL tasks & Teacher's role in CL \\
\hline
\end{tabular}

Thank you very much for participating in my research.

\section{Appendix 2}

\section{Observation sheet}

Teacher name:

Lesson:

Time:.

\begin{tabular}{|l|l|l|l|}
\hline Teacher's role in CL & Applied & Sometimes applied & Not applied \\
\hline Appropriate design of meaningful tasks. & & & \\
\hline Is clear about the task information. & & & \\
\hline Scaffolds and monitors the learning process. & & & \\
\hline Evaluates the students' learning during CL. & & & \\
\hline Provides useful feedback on CL. & & & \\
\hline Carefully chooses CL resources. & & & \\
\hline
\end{tabular}

\begin{tabular}{|l|l|l|l|}
\hline CL environment & Applied & Sometimes applied & Not applied \\
\hline Desks arranged in the classroom so students face each other. & & & \\
\hline Teacher can easily move between groups and around the classroom. & & & \\
\hline All necessary resources available in advance on the desks. & & & \\
\hline Resources are for each group, not for individuals. & & & \\
\hline Resources placed in a central location. & & & \\
\hline
\end{tabular}

\begin{tabular}{|l|l|l|l|}
\hline CL group formation and dynamic & Applied & Sometimes applied & Not applied \\
\hline Ideal group size (3-6 members). & & & \\
\hline Randomly assigned group members. & & & \\
\hline Heterogeneous groups. & & & \\
\hline Teacher explains each student's role requirements. & & & \\
\hline Groups evaluate how well members carry out their specific duties. & & & \\
\hline
\end{tabular}




\begin{tabular}{|l|l|l|l|}
\hline CL tasks & Applied & Sometimes applied & Not applied \\
\hline Academic task has a shared group goal. & & & \\
\hline Success criteria is explicit and linked to the shared goal. & & & \\
\hline Individual accountability incorporated into the task assessment. & & & \\
\hline Details provided about completing the task. & & & \\
\hline Only one copy of the task provided to each group. & & & \\
\hline Set time limits for the assigned tasks. & & & \\
\hline
\end{tabular}

\section{Appendix 3}

The questions for the teachers' daily reports after applying the CL procedures in their EFL lessons

- What was your lesson's topic?

- What were your lesson's aims?

- How did you organize CL?

- What tasks did you give the students?

- How did you explain the group members' roles?

- How did you motivate and encourage the students to participate in CL with you?

- What are your reflections on applying the CL instructions?

- What are the students' reflections on organizing and applying the CL instructions?

\section{Appendix 4}

\section{Open-ended EFL teacher questionnaire}

- Name

- Age.

- Years of experience.

- Grade that you teach

- Number of students.

1. What are the procedures that you focused on while applying CL?

2. What tasks did you provide your students to encourage their CL interactions?

3. How did you help your students if they were not cooperating with each other?

4. Do you think that the procedures helped you make CL more effective? 
5. What are the challenges you faced while applying CL?

6. Did you apply other or different CL procedures?

\section{REFERENCES}

[1] Abdu-Raheem B. O., "Effects of Discussion Method on Secondary School Students' Achievement and Retention in Social Studies," European Journal of Educational Studies, vol. 3, no. 2, pp. 293-301, 2011. https://doi.org/10.19030/ji er.v8i1.6692

[2] Adewuya S. A., Social Science Methods, Green Line Publishers, 2003.

[3] Alghamdi R., "EFL Learners' Behaviour States During Cooperative Learning Strategy," International Journal of Linguistics, vol. 10, no. 6, pp. 4-10, 2018. DOI: 5296/ijl.v10i6.14006

[4] Alghamdi R., Gillies R., "The Impact of Cooperative Learning in Comparison to Traditional Learning (Small Groups) on EFL Learners' Outcomes when Learning English as a Foreign Language," Asian Social Science, vol. 9, no. 13 , 2013. DOI: 10.5539 /ass.v9n13p19

[5] Alharbi L. A., The Effectiveness of Using Cooperative Learning Method on ESL Reading Comprehension Performance, Students' Attitudes toward CL, and Students' Motivation toward Reading of Secondary Stage in Saudi Public Girls' Schools (Unpublished doctoral dissertation) West Virginia University, USA, 2008.

[6] Allan S. D., “Ability-Grouping Research Reviews: What Do They Say about Grouping and the Gifted?", Educational Leadership, vol. 48, no. 6, pp. 60-65, 1991.

[7] Azizinezhad M., Hashemi M., S. Darvishi, "Application of Cooperative Learning in EFL Classes to Enhance the Students' Language Learning," Procedia-Social and Behavioral Sciences, vol. 93, pp. 138-141, 2013. DOI: 10.1016/j.sbspro.2013.09.166

[8] Asgarikia, P., "The Effects of Task Type, Strategic Planning and No Planning on Written Performance of Iranian Intermediate EFL Learners", Procedia - Social and Behavioral Sciences. vol.98, pp.276-285, 2014, 10.1016/j.sbspro.2014.03.417.

[9] Bachman C. H., Using Learning Styles as a Group Selection Technique. Unpublished manuscript, Center for Teaching Excellence at New York, 2010.

[10] Barkley E. F., Cross K. P., C. H. Major, Collaborative Learning Techniques: A Handbook for College Faculty, Jossey-Bass, 2014.
[11] Birmingham C., McCord M., "Group Process Research: Implications for Using Learning Groups," in Team-Based Learning: A Transformative Use of Small Groups in College Teaching, Stylus, 2004, pp. 73-93.

[12] Brookes A., Grundy P., Writing for Study Purposes: A Teacher's Guide Developing Individual Writing Skills, Cambridge University Press, 1990.

[13] Brown D., Teaching by Principles: An Interactive Approach to Language Pedagogy, 2nd ed, Prentice Hall Regents, 2001.

[14] Chapman K. J., Meuter M., Toy D., L. Write, “Can’t We Pick Our Own Group? The Influence of Group Selection Method on Group Dynamics and Outcomes," Journal of Management Education, vol. 30, pp. 557-569, 2006.

[15] Cohen E. G., Designing Groupwork: Strategies for the Heterogeneous Classroom, 2014.

[16] Dillon J., Cheney J., "Building the Team: Assessing Two Design Group Formation Methodologies," The ASEE Annual Conference and Composition, NY, USA, 2009.

[17] Dörnyei Z., Research Methods in Applied Linguistics: Quantitative, Qualitative, and Mixed Methodologies, Oxford University Press, 2007.

[18] Freeman R., "The Importance of Participant Role in Cooperative Learning," Working Papers in Educational Linguistics, vol. 9, no. 1, pp. 1-20, 1993. https://repository.upenn.edu/wpel/vol9/iss1/1

[19] Gage N. L., Berliner D. C., Educational Psychology, Houghton Mifflin, 2002.

[20] Gagné N., Parks S., "Cooperative Learning Tasks in a Grade 6 Intensive ESL Class: Role of Scaffolding," Language Teaching Research, vol. 17, no. 2, pp. 188-209, 2013. https://doi.org/10.1177/1362168812460818

[21] Gillies R. M., "Teachers' and Students' Verbal Behaviours during Cooperative and Small-Group Learning," British Journal of Educational Psychology, vol. 76, pp. 271-287, 2006. DOI: 10.1348/000709905X52337

[22] Gillies R. M., "Structuring Cooperative Group Work in Classrooms," International Journal of Educational Research, vol. 39, no. 1-2, pp. 35-49, 2003. DOI: $10.1016 / \mathrm{S} 0883-0355(03) 00072-7$

[23] Gillies R. M., "The Effects of Cooperative Learning on Junior High School Students during Small Group Learning," Learning and Instruction, vol. 14, no. 2, pp. 197-213, 2004. DOI: $10.1016 / \mathrm{S} 0959-4752(03) 00068-9$

[24] Gillies R. M., Ashman A. F., J. Terwel, The Teacher's Role 
in Implementing Cooperative Learning in the Classroom, Springer, 2008. http://dx.doi.org/10.1007/978-0-387-708928

[25] Gilles R., Boyle M., “Teachers' reflections on cooperative learning: issues of implementation," Teaching and Teacher Education. vol. 26, pp.933-940., 2010. http://dx.doi.org/10. 1016/j.tate.2009.10.034.

[26] Hassaskhah J., Mozaffari H., "The Impact of Group Formation Method (Student-Selected vs. Teacher-Assigned) on Group Dynamics and Group Outcome in EFL Creative Writing," Journal of Language Teaching \& Research, vol. 6, no. 1 , pp. 147-156, 2015. https://doi org.sdl.idm.oclc.org/10.17507/jltr.0601.18

[27] Hilton S., Philips F., "Instructor-Assigned and Student-Selected Groups: A View from Inside," Issues in Accounting Education, vol. 25, no. 1, pp. 15-33, 2008. DOI: 10.2308/iace.2010.25.1.15

[28] Iman J. N., Angraini N., Discussion Task Model in EFL Classroom: EFL Learners' Perception, Oral Proficiency, and Critical Thinking Achievements, Pedagogika, Vol. 133, no.1, pp. 43-32, 2019. https://doi.org/10.15823/p.2019.133.3

[29] Johnson D. W., Johnson R. T., "Cooperative Learning and Social Interdependence Theory," in Theory and Research on Small Groups, Plenum, 1998, pp. 9-35.

[30] Johnson D. W., Johnson F., Joining Together: Group Theory and Group Skills, 4th ed, Prentice Hall, 2017.

[31] Koppenhaver G. D., Shrader C. B., "Structuring the Classrooms for Performance: Cooperative Learning with Instructor-Assigned Teams," Decision Sciences Journal of Innovative Education, vol. 1, no. 1, pp. 1-21, 2003. DOI: 10.1111/1540-5915.00002

[32] Kyndt, E., Raes, E., Lismont, B., Timmers, F., Cascallar, E. \& Dochy, F., "A meta- analysis of the effects of face-to-face cooperative learning. Do recent studies falsify or verify earlier findings?," Educational Research Review, vol.10, pp.133-149., 2013. DOI. 10.1016/j.edurev.2013.02.002.

[33] Lou, Y., Abrami, P. C., \& d'Apollonia, S. "Small Group and Individual Learning with Technology: A Meta-Analysis," Review of Educational Research, Vol.71., no 3., 449-521., 2001, https://doi.org/10.3102/00346543071003449

[34] Mahenthiran S., Rouse P., "The Impact of Group Selection on Student Performance and Satisfaction," The International Journal of Education Management, vol. 14, no. 6, pp. 255-265, 2000. https://doi.org/10.1108/09513540010 348043

[35] Mahmoud M. M., "The Effectiveness of Using the Cooperative Language Learning Approach to Enhance EFL Writing Skills among Saudi University Students," Journal of Language Teaching \& Research, vol. 5, no. 3, pp. 616-625, 2014. DOI: $10.4304 /$ jltr.5.3.616-625

[36] McCafferty S. G., Jacobs G. M., I. A. C. DaSilva, Cooperative Learning and Second Language Teaching, Cambridge University Press, 2006.

[37] Millis B. J., "Using Cooperative Structures to Promote Deep Learning," Journal on Excellence in College Teaching, vol.
25, no. 3/4, pp. 139-148, 2014. http://jufsusanne.nl/files/upl oads/deep-learning-artikelen/v25n34-millis.pdf

[38] Mitchell S. N., Reilly R., Bramwell G., Solnosky A., F. Lilly, "Friendship and Choosing Groupmates: Preferences for Teacher-Selected vs. Student-Selected Groupings in High School Science Classes," Journal of Instructional Psychology, vol. 31, no. 1, pp. 20-32, 2004.

[39] Mushtaq R., Murteza G., Rashid S., A. Khalid, “The Influence of Group Selection Method on Grades, Performance and Group Outcome," Journal of Basic and Applied Scientific Research, vol. 2, no. 7, pp. 7003-7008, 2012.

https://www.textroad.com/pdf/JBASR/J.\%20Basic.\%20Ap pl.\%20Sci.\%20Res.,\%202(7)7003-7008,\%202012.pdf

[40] Oakley B., Felder R. M., Brent R., I. Elhajj, "Turning Student Groups into Effective Teams," Journal of Student Centered Learning, vol. 2, no. 1, pp. 9-34, 2004. http://www.ncsu.edu/felder-public/Papers/Oakley-paper(JS CL).pdf

[41] Roberts J., “The 'More Capable Peer': Approaches to Collaborative Learning in a Mixed-Ability Classroom. Changing English," Studies in Culture and Education, vol. 23, no. 1, pp. 42-51, 2016. http://search.ebscohost.com.sdl.i dm.oclc.org/login.aspx?direct $=$ true $\& \mathrm{db}=$ eric $\& \mathrm{AN}=\mathrm{EJ} 1107$ $304 \&$ site $=$ eds-live

[42] Robinson P., "Task-Based Language Learning: A Review of Issues," Language Learning, vol. 61, no. 1, pp. 1-36, 2011. https://doi.org/10.1111/j.1467-9922.2011.00641.x

[43] Russell M., "The Formation of Effective Work Groups within an FE Classroom," Research in Post-compulsory Education, vol. 15, no. 2, pp. 205-221, 2012. DOI: $10.1080 / 13596741003790765$

[44] Ryoo H. K., "Discussion Task as a Method of Oral Proficiency Test: Responding to the Others," Journal of Linguistic Science, vol. 55, pp. 29-50, 2010.

[45] Shindler J., Transformative Classroom Management: Positive Strategies to Engage all Students and Promote a Psychology of Success, Jossey-Bass Publishers, 2010.

[46] Shimazoe J., Aldrich H., "Group Can Be Gratifying: Understanding and Overcoming Resistance to Cooperative Learning," College Teaching, vol. 58, no. 2, pp. 52-57, 2010. DOI: $10.1080 / 87567550903418594$

[47] Siciliano J. I., "How to Incorporate Cooperative Learning Principles in the Classroom: It's More than Just Putting Students in Teams," Journal of Management Education, vol. 25 , no. 1, pp. 8-20, 2001. https://doi.org/10.1177/10525629 0102500103

[48] Stephen D., Stephen P., Discussion as a Way of Teaching, Jossey Bass Press, A Willey Imprint, 2005.

[49] Willis, J. A., "Framework for Task-based Learning, London,'” Longman, 1996,.

[50] Yusuf N., Al-Banawi N., "The Impact of Changing Technology: e-Case of E-learning," International Journal of Contemporary Issues in Education, vol. 6, no. 2, pp. 173180,2013 